Harris, P. L., Ames, S. R. \& Brinkman, J. H. (195 I). F. Amer. chem. Soc. 73, 1252.

Harrison, G. F. (1956). Private communication.

Henry, K. M. (1956). Private communication.

Henry, K. M. \& Thompson, S. Y. (1954). Milchwissenschaft, 9, 14.

Henry, K. M., Kon, S. K., Mawson, E. H., Stanier, J. E. \& Thompson, S. Y. (1949). Brit.F.Nutr.3, 30r .

Ingle, D. J. \& Griffith, J. Q. (1949). In The Rat in Laboratory Investigation, and ed., p. 448. [E. H. Farris and J. Q. Griffith, editors.] London: J. B. Lippincott Company.

Long, J. A. \& Evans, H. McL. (r922). Mem. Univ. Calif. Vol. 6.

Pederson-Bjergaard, K. (1939). Comparative Studies Concerning the Strengths of Estrogenic Substances. Oxford University Press.

Plack, P. A. (1956). Biochem. F. 64, 56.

Plack, P. A., Fisher, L. R., Henry, K. M. \& Kon, S. K. (r956). Biochem. F. 64, I7P.

Pugsley, L. I., Wills, G. \& Crandall, W. A. (1944). F. Nutr. 28, 365.

Thompson, S. Y. (1949). Brit. F. Nutr. 3, 43.

Thompson, S. Y., Ganguly, J. \& Kon, S. K. (1949). Brit. 7. Nutr. 3, 50.

\title{
Factors influencing the rate of excretion of administered chromium sesquioxide by steers
}

\author{
By C. C. BALCH*, J. T. REID AND J. W. STROUD \\ Animal Husbandry Department, Cornell University, Ithaca, New York \\ (Received 29 October 1956)
}

Inert markers such as chromium sesquioxide $\left(\mathrm{Cr}_{2} \mathrm{O}_{3}\right)$ are frequently used in digestion experiments to calculate, by means of the ratio technique, the weight of faeces produced; this procedure makes the complete collection of faeces unnecessary. Although earlier the suitability of this method for studies with ruminants was sometimes criticized, it is now widely used with these animals for normal digestibility trials and gives satisfactory results provided the $\mathrm{Cr}_{2} \mathrm{O}_{3}$ is thoroughly mixed with the food (Edin, Kihlén \& Nordfeldt, 1944-5).

In measurements of the intake of grazing animals $\mathrm{Cr}_{2} \mathrm{O}_{3}$ used as a marker provides a means of determining the output of faeces. This is again a considerable saving in labour as it avoids the difficulties of collecting faeces quantitatively from grazing cows or steers. In many experiments in New Zealand and in the United States the number of daily samples of faeces has been limited to two, and the results have shown satisfactory agreement with those obtained by the total collection of faeces. With dairy cows an ideal and common arrangement is for the $\mathrm{Cr}_{2} \mathrm{O}_{3}$ to be given, and rectal samples of faeces to be taken, while the cows are at the milking shed. The use of this procedure might be taken to imply that the content of $\mathrm{Cr}_{2} \mathrm{O}_{3}$ in the faeces remains constant throughout the $24 \mathrm{~h}$. However, investigation has shown that there is a considerable diurnal variation. In grazing cows given $\mathrm{Cr}_{2} \mathrm{O}_{3}$ once daily at about $07 \cdot 3 \circ \mathrm{h}$ there was a low point at $\mathrm{I} 2.00$ and a peak at $\mathrm{I} 8.00 \mathrm{~h}$; the concentration at the low point was 50 , and at the high point $180 \%$, of the mean $\mathrm{Cr}_{2} \mathrm{O}_{3}$ content of the faeces (Hardison \& Reid, 1953). These workers also found that in hand-fed steers, receiving two meals of cut herbage daily at $06.00 \mathrm{~h}$ and $16.00 \mathrm{~h}$, and $\mathrm{Cr}_{2} \mathrm{O}_{3}$ at $07.00 \mathrm{~h}$, there was also a diurnal

* On leave from the National Institute for Research in Dairying, Shinfield, near Reading, England. 
variation, but in this instance the peak was at $04.00 \mathrm{~h}\left(\mathrm{r} 30 \%\right.$ of mean $\mathrm{Cr}_{2} \mathrm{O}_{3}$ content of faeces) and the low point at $20.00 \mathrm{~h}(80 \%)$. With cows fed on a mixed ration (containing $\mathrm{Cr}_{2} \mathrm{O}_{3}$ mixed with the concentrates) at 05.00 and $\mathrm{I} 3.00 \mathrm{~h}$, Kane, Jacobson \& Moore (1952) found that peaks occurred in the period 08.00-12.00 $\mathrm{h}$ (according to calculations made by Hardison \& Reid (1953) the values at these times were ro8I I $\%$ of the mean $\mathrm{Cr}_{2} \mathrm{O}_{3}$ content of the daily faeces) and low points at $16.00-20.00 \mathrm{~h}$ $(92-94 \%)$. The curves followed the same general shape as those found in the animals of Hardison \& Reid receiving grass indoors, but the difference in method of administering the $\mathrm{Cr}_{2} \mathrm{O}_{3}$ considerably reduced the range of concentration in the faeces. In an experiment in New Zealand, on sheep either grazing or being fed indoors, Lambourne (1955) obtained satisfactory estimates of faeces production with a routine in which $\mathrm{Cr}_{2} \mathrm{O}_{3}$ was administered and samples of faeces were taken at alternate intervals of 9 and $\mathrm{I} 5 \mathrm{~h}$.

In the digestive tract of the ruminant, the separation of a marker from the food with which it was given, or any accumulation of the marker, is most likely to take place in the reticulo-rumen. Separation or accumulation seems less likely to occur in the remainder of the gut. It is therefore probable that, apart from the effect of gastric and intestinal digestion, the concentration of $\mathrm{Cr}_{2} \mathrm{O}_{3}$ in the faeces will be related to that in the digesta passing through the reticulo-omasal orifice. In the present work, therefore, steers with rumen fistulas were used to study the fate of $\mathrm{Cr}_{2} \mathrm{O}_{3}$ in the reticulo-rumen.

Certain features common to all the available values for the diurnal variation in the $\mathrm{Cr}_{2} \mathrm{O}_{3}$ content of faeces suggested that those variations were partly independent of the nature of the diet but were influenced by occurrences happening once every $24 \mathrm{~h}$ in all cattle. Two possible causes were, therefore, $(a)$ the marked tendency for cattle to lie most of the night and to stand during the day, and $(b)$ the equally marked tendency for eating to be mainly concentrated into the daylight hours; this latter trend is particularly apparent under grazing conditions, but also occurs in stall-fed animals because of unequal intervals between feeding. The relationship of the main periods of eating to the time of administration of $\mathrm{Cr}_{2} \mathrm{O}_{3}$ seemed especially likely to influence the concentration of $\mathrm{Cr}_{2} \mathrm{O}_{3}$ in the faeces. Two experiments were accordingly conducted on stall-fed steers. In the first the feeding intervals were standardized, $\mathrm{Cr}_{2} \mathrm{O}_{3}$ being given at the beginning of each feed and the posture of animals, standing or lying, being controlled. In the second experiment the animals were fed only once daily and the effect of giving the $\mathrm{Cr}_{2} \mathrm{O}_{3}$ before or after feeding was investigated.

\section{METHODS}

Two experiments were conducted on two yearling Holstein steers (A and D) weighing about $600 \mathrm{lb}$. Throughout both experiments they received daily ro lb. timothy hay, $5 \mathrm{lb}$. of a ground dairy concentrate and $47 \mathrm{lb}$. water. Large rumen fistulas were inserted 6 weeks before the beginning of Exp. I and each was closed by means of a rubber cannula and bung (Balch \& Johnson, 1948).

Preliminary trials showed that when capsules of $\mathrm{Cr}_{2} \mathrm{O}_{3}$ were given to the steers by balling gun, the procedure usual in grazing experiments, they fell from the cardia into either the atrium ventriculi or the reticulum and, in the few minutes required for their disintegration, might readily move between these two compartments. In the 
experiments, the capsules containing io $\mathrm{g}$ finely ground $\mathrm{Cr}_{2} \mathrm{O}_{3}$ and a carrier were, therefore, placed at the cardia.

In both experiments the daily intake of $\mathrm{Cr}_{2} \mathrm{O}_{3}$ amounted to $3.34 \mathrm{mg} / \mathrm{g}$ food dry matter.

\section{Exp. I. Effect of standing and lying on excretion}

The steers received their daily allowance of food and water in two equal feeds, at 09.00 and $2 \mathrm{r} .00 \mathrm{~h}$; they required $2-2.5 \mathrm{~h}$ to consume the feeds completely. The $\mathrm{Cr}_{2} \mathrm{O}_{3}$ ( $1 \circ \mathrm{g}$ ) was administered $\mathrm{I}_{5}-20 \mathrm{~min}$ after the beginning of the feed and the water was given towards the end of feeding.

The experiment was in two parts. In part I the steers stood from 09.00 to $21.00 \mathrm{~h}$ and in part 2 from 21.00 to $09.00 \mathrm{~h}$. Standing was assured by means of leather girths attached to a rope suspended from the ceiling of the building. When released from the ropes the steers lay down almost continuously throughout the following $\mathrm{I} 2 \mathrm{~h}$.

The contents of the reticulo-rumen were removed, weighed, sampled and returned immediately before feeding on 3 days in part $\mathrm{I}$ of the experiment and on 2 days in part 2. On I day in each part the contents were also removed as soon as the food had been eaten. The removal, sampling and return of the contents required about $25 \mathrm{~min}$ in each steer and caused them no apparent pain.

\section{Exp. 2. Effect of time of administration on the excretion of $\mathrm{Cr}_{2} \mathrm{O}_{3}$}

Both steers received the full daily allowance of food and water in a single feed at about $09.00 \mathrm{~h}$ daily throughout the two parts of the experiment. They were accustomed to this method of feeding for 3 weeks before the experiment began.

Each steer received $20 \mathrm{~g} \mathrm{Cr}_{2} \mathrm{O}_{3}$ (two capsules) immediately before feeding, i.e. at 09. $\mathrm{I} \circ \mathrm{h}$, in part $\mathrm{I}$ of the experiment and immediately after feeding, i.e. at about $\mathrm{I} 2.30 \mathrm{~h}$, in part 2 .

The contents of the reticulo-rumen were removed, weighed, sampled and returned before, at the end of, and 5-6 h after the end of feeding on 2 days in each part of the experiment. In part 2 the $\mathrm{Cr}_{2} \mathrm{O}_{3}$ was given when the contents had been returned after eating.

\section{Samples}

Total contents of reticulo-rumen. The dry-matter content of the mixed contents was determined at $100^{\circ}$ in duplicate samples of $200-300 \mathrm{~g}$. Agreement between duplicates was good and the dried residues were retained for analysis.

Reticulum. In Exp. I, before removal of the total contents, samples of the digesta in the reticulum were taken in a small beaker, the top of which was closed by the operator's hand during insertion and removal.

Digesta near reticulo-omasal orifice. Samples of the digesta lying near the reticuloomasal orifice were similarly taken in a small beaker.

Faeces. Samples were taken from the rectum.

\section{Chemical analysis}

Chromium was determined in individual samples dried to constant weight at $100^{\circ}$. With minor modifications, the method used was essentially that described by Bolin, 
King \& Klosterman (1952). As soon as chromic acid was formed (i.e. when the solution changed colour) the solution was chilled and immediately diluted with water to avoid peroxide formation and the resultant formation of $\mathrm{Cr}\left(\mathrm{ClO}_{4}\right)_{3}$. Samples having a low concentration of $\mathrm{Cr}_{2} \mathrm{O}_{3}$ were analysed in large quantities. As much as $\mathrm{Iog}$ of such samples were predigested with $\mathrm{HNO}_{3}$ to destroy most of the organic matter before analysis.

RESULTS

\section{Exp. I. Effect of standing and lying on excretion}

The values obtained by completely emptying the reticulo-rumen are given in Table I. The total weight, weight of dry matter, weight of water and percentage of dry matter in the digesta in the reticulo-rumen before feeding were clearly the same whether the animal had been standing or lying in the preceding $\mathrm{I} 2 \mathrm{~h}$. This must mean that the overall loss of water and of dry matter during and after each feed was the same night and day. These losses are brought about by absorption through the stomach wall and by passage to the omasum and evidently equalled, in the periods of observation, the additions made to the reticulo-rumen as food, water and saliva. In view of the constancy found in the measurements of the contents it is probable that the amount of dry matter passing to the omasum was the same night and day.

In Table I are also shown the concentration of $\mathrm{Cr}_{2} \mathrm{O}_{3}$ in the total contents of the reticulo-rumen and in the contents of the reticulum. Neither the concentration nor the actual weight of $\mathrm{Cr}_{2} \mathrm{O}_{3}$ in the reticulo-rumen was affected by the previous posture of the animal. There was noted, however, a tendency for the concentration of $\mathrm{Cr}_{2} \mathrm{O}_{3}$ in the dry digesta to be slightly higher in the reticulum than in the whole mixed contents of the reticulo-rumen. This finding suggests a slight tendency for $\mathrm{Cr}_{2} \mathrm{O}_{3}$ to accumulate in the reticulum.

In Exp. I samples of the digesta lying close to the reticulo-omasal orifice were collected on only I day. These showed (Fig. I) that immediately after feeding, the concentration of $\mathrm{Cr}_{2} \mathrm{O}_{3}$ was at its peak. There was then a distinct fall followed by a recovery, the level at $10.35 \mathrm{~h}$ being lower than the subsequent values until $2 \mathrm{r} .00 \mathrm{~h}$. After the steers had spent $12 \mathrm{~h}$ lying or standing the $\mathrm{Cr}_{2} \mathrm{O}_{3}$ contents of the total digesta were, respectively, only $\mathrm{I}^{\prime} 3 \mathrm{I}$ or $\mathrm{I} \cdot \mathrm{I} / \mathrm{mg} / \mathrm{g}$ dry matter. Since $\mathrm{Cr}_{2} \mathrm{O}_{3}$ was administered with the food at the rate of $3.34 \mathrm{mg} / \mathrm{g}$ dry matter, $\mathrm{Cr}_{2} \mathrm{O}_{3}$ must have been lost from the reticulo-rumen at a rate proportionately higher than dry matter. The concentration of $\mathrm{Cr}_{2} \mathrm{O}_{3}$ in the digesta from the orifice did not reach $3.34 \mathrm{mg}$ (maximum $\mathrm{I}_{4} \cdot \mathrm{mg}$ in steer $\mathrm{A}$ and $2 \cdot 2 \mathrm{mg}$ in steer D) even in samples taken $30 \mathrm{~min}$ after the administration of the marker. It would appear, however, from Fig. I, that there must have been a very high rate of passage of $\mathrm{Cr}_{2} \mathrm{O}_{3}$ to the omasum in the Ist $\mathrm{h}$ after administration. This assumption was proved when the reticulo-rumen was emptied immediately after eating had ended, the concentrations of $\mathrm{Cr}_{2} \mathrm{O}_{3}$ being then little different from those found $\mathrm{I} 2 \mathrm{~h}$ after feeding. The weights of $\mathrm{Cr}_{2} \mathrm{O}_{3}$ in the reticulo-rumen of steer $\mathrm{A}$ at $09.00 \mathrm{~h}$ on these 2 days were 4.43 and $4.50 \mathrm{~g}$, and in steer D 5.64 and $4.5^{8} \mathrm{~g}$, respectively. The steers were then given $5 \mathrm{lb}$. hay, $2.5 \mathrm{lb}$. concentrates and $10 \mathrm{~g}_{2} \mathrm{Cr}_{3}$, and yet after the 2-3 $\mathrm{h}$ required for consumption of the food only 6.59 and $6.74 \mathrm{~g} \mathrm{Cr}_{2} \mathrm{O}_{3}$ 


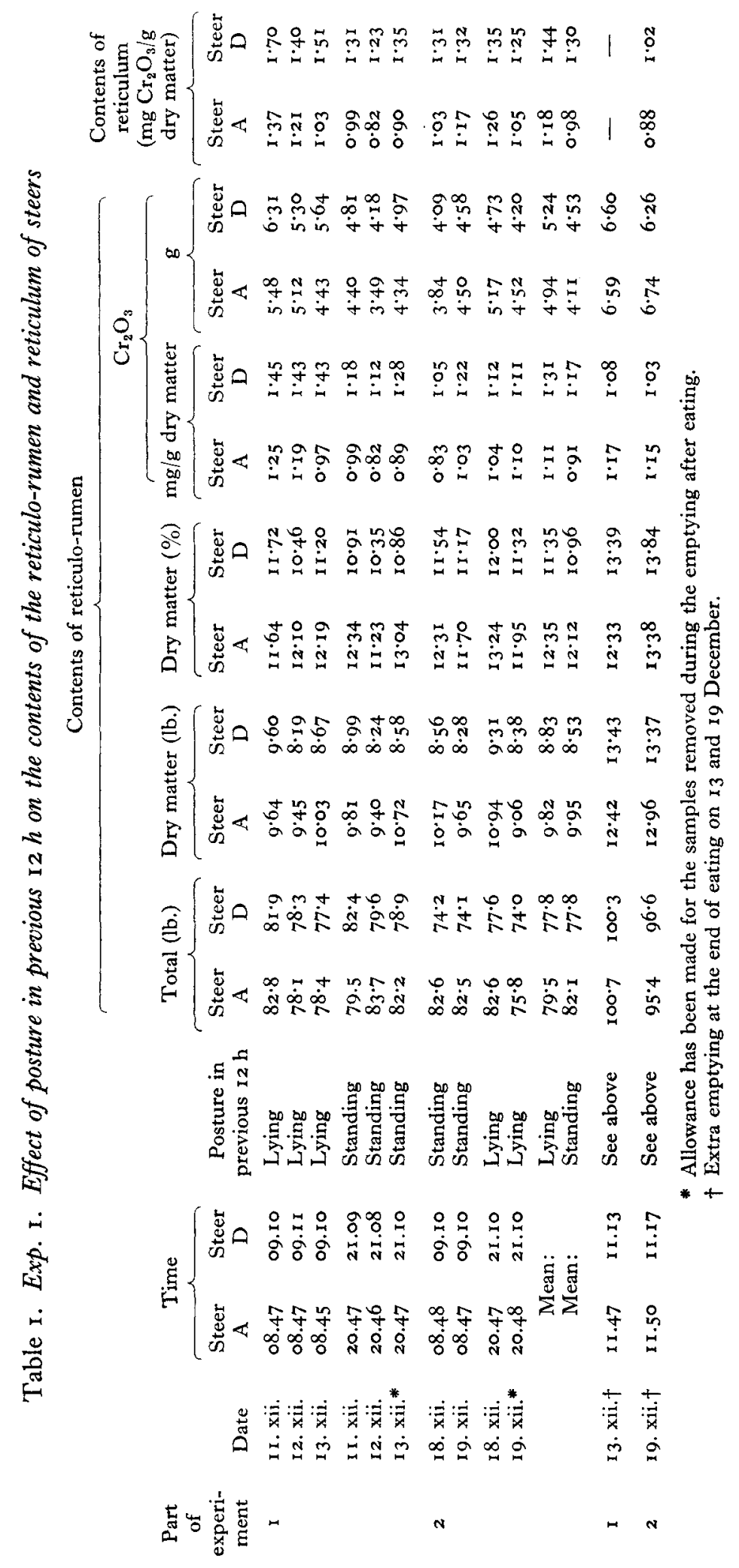


were found in steer $A$ and 6.60 and 6.26 in steer D. This finding demonstrates the substantial passage of $\mathrm{Cr}_{2} \mathrm{O}_{3}$ that occurred during periods of eating which followed the administration of $\mathrm{Cr}_{2} \mathrm{O}_{3}$ by capsule.

The effect of this variation in excretion rate on the concentration of $\mathrm{Cr}_{2} \mathrm{O}_{3}$ in the faeces is shown in Fig. 2. In each part of the experiment the concentration followed the same general pattern. Irrespective of when the steers were lying and standing there

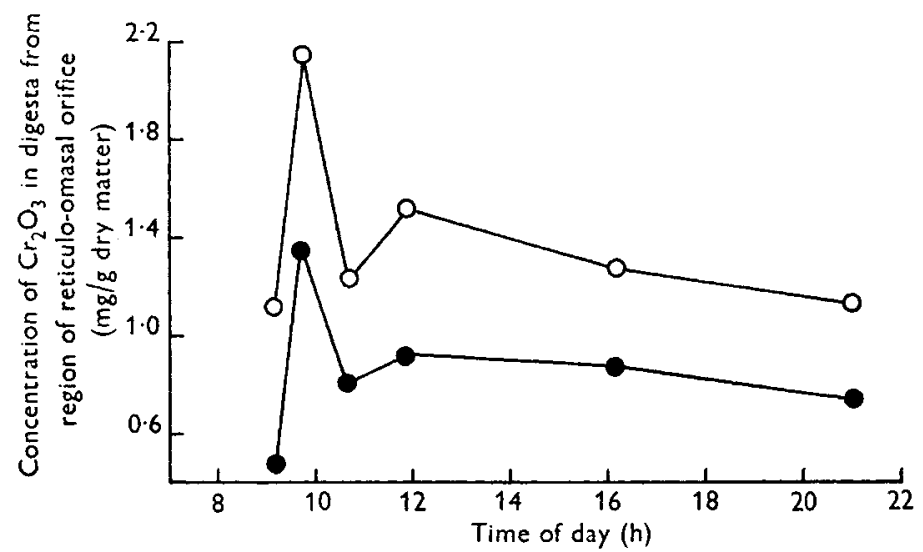

Fig. 1. Exp. 1. Concentration of $\mathrm{Cr}_{2} \mathrm{O}_{3}$ in digesta from the region of the reticulo-omasal orifice in steer $\mathrm{A},-\mathrm{O}$, and steer $\mathrm{D}, \mathrm{O}-\mathrm{O}$. The $\mathrm{IO} \mathrm{g}$ capsules of $\mathrm{Cr}_{2} \mathrm{O}_{3}$ were given at $09.20 \mathrm{~h}$.

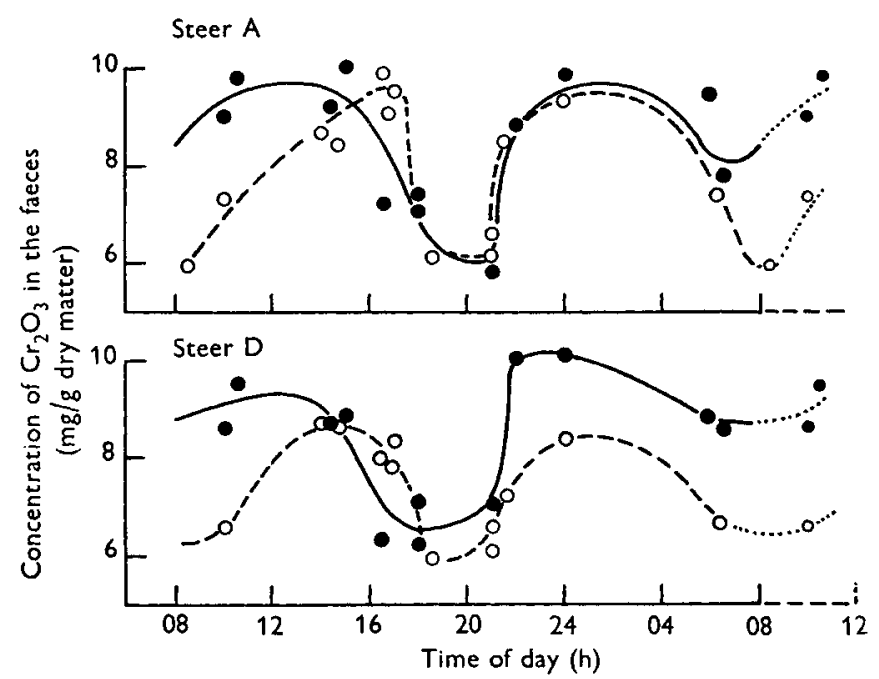

Fig. 2. Exp. 1. Concentration of $\mathrm{Cr}_{2} \mathrm{O}_{3}$ in the faeces from steers $\mathrm{A}$ and $\mathrm{D}$ given $10 \mathrm{~g}$ capsules of $\mathrm{Cr}_{2} \mathrm{O}_{3}$ at 09.20 and $21.20 \mathrm{~h}$. The steers were either standing from 09.00 to $2 \mathrm{r} .00 \mathrm{~h}$ and lying from 21.00 to $09.00 \mathrm{~h},-0$, or lying from 09.00 to $2 \mathrm{I} .00 \mathrm{~h}$ and standing from 21.00 to $09.00 \mathrm{~h}, 0--0$. To demonstrate the continuation of the curve, values for the period $08.00-12.00 \mathrm{~h}$ have been repeated on the right of the figure, with small circles and dotted lines.

was a marked fall in the concentration of $\mathrm{Cr}_{2} \mathrm{O}_{3}$ in the faeces produced in the period I9.00-21.00 h. There was some indication of a second fall in concentration in the period $06.00-09.00 \mathrm{~h}$, especially when the animals were lying down by day, but the number of samples available for this period was inadequate to show this fall fully. 


\section{Exp. 2. Effect of the time of administration of $\mathrm{Cr}_{2} \mathrm{O}_{3}$ on its excretion}

The values obtained when the reticulo-rumen was emptied are given in Table 2. The total weight, weight of dry matter, weight of water and percentage of dry matter in the digesta in the reticulo-rumen before, immmediately after, and $6 \mathrm{~h}$ after the single daily feed were similar in both parts of the experiment. Any differences in the weight or concentration of $\mathrm{Cr}_{2} \mathrm{O}_{3}$ in the digesta or faeces during the two parts are likely, therefore, to be the result of the different times of administration.

Table 2. Exp. 2. Contents of the reticulo-rumen of steers

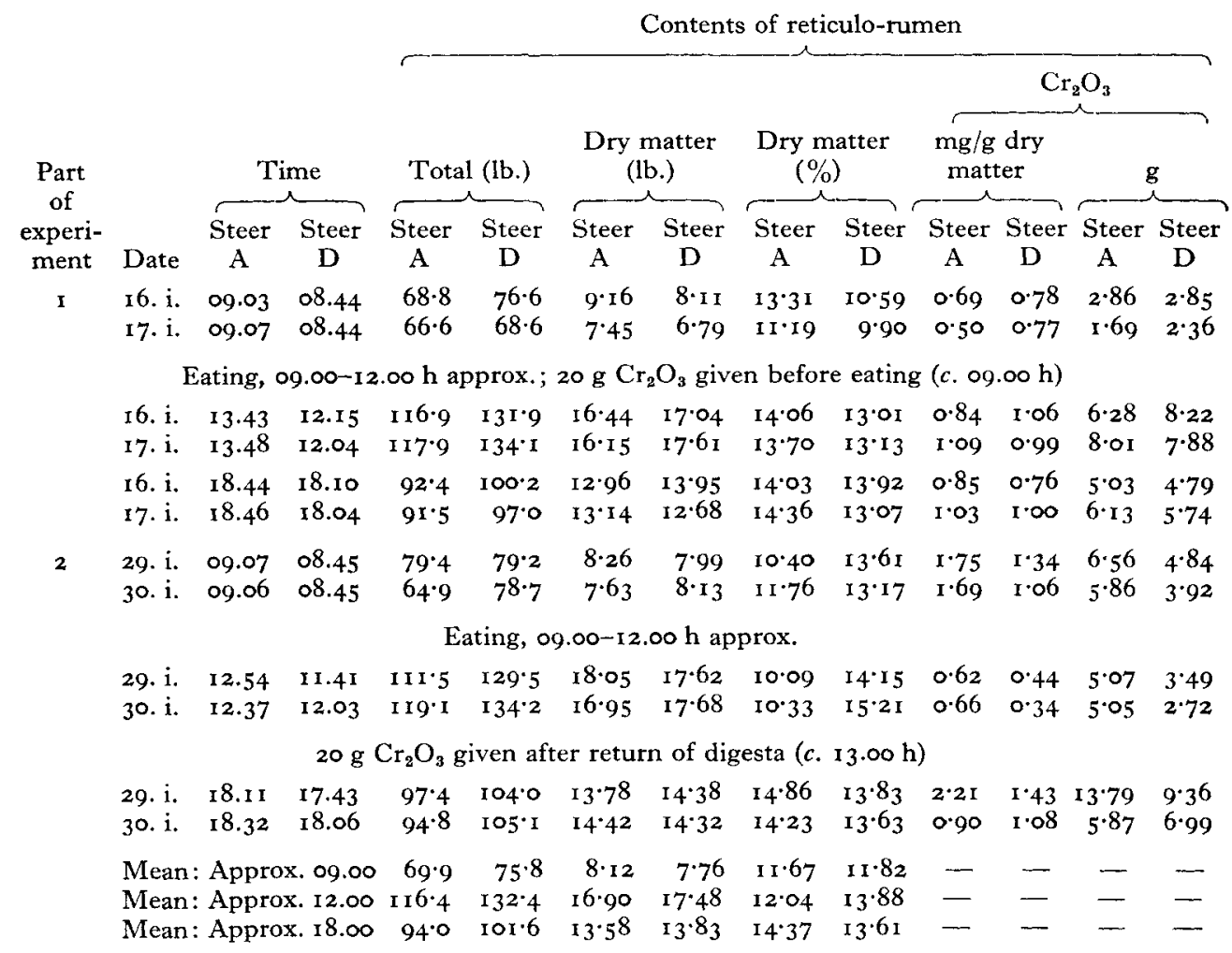

The concentration of $\mathrm{Cr}_{2} \mathrm{O}_{3}$ in the digesta removed from the reticulo-rumen never approached the concentration in the intake. In part $\mathrm{I}$ of the experiment, when the $\mathrm{Cr}_{2} \mathrm{O}_{3}$ was given before the food, the concentration was relatively constant $(0 \cdot 8$ $\mathrm{I} \cdot \mathrm{I} \mathrm{mg} / \mathrm{g}$ dry matter) at $\mathrm{I2.00}$ and $\mathrm{I} 8.00 \mathrm{~h}$, but declined somewhat during the night. Before the morning feed the values were $0.5-0.8 \mathrm{mg}$. It was also interesting to find that although $\mathrm{I}^{\prime} \cdot 7^{-2} \cdot 9 \mathrm{~g} \mathrm{Cr}_{2} \mathrm{O}_{3}$ were present in the reticulo-rumen, and $20 \mathrm{~g} \mathrm{Cr}_{2} \mathrm{O}_{3}$ were administered immediately before feeding, only $6 \cdot 3-8 \cdot 2 \mathrm{~g}$ were present at the end of the feed. This finding also shows that there was a rapid loss of $\mathrm{Cr}_{2} \mathrm{O}_{3}$ from the reticulorumen while the food was being eaten.

When in part 2, the $\mathrm{Cr}_{2} \mathrm{O}_{3}$ was given after feeding, the concentrations in the digesta were highly variable. At the end of the feed the digesta contained $0.3-0.7 \mathrm{mg} \mathrm{Cr}_{2} \mathrm{O}_{3} / \mathrm{g}$ 
dry matter and (when allowance was made for the samples removed) the addition of $20 \mathrm{~g} \mathrm{Cr}_{2} \mathrm{O}_{3}$ raised the concentration of $\mathrm{Cr}_{2} \mathrm{O}_{3}$ to $2 \cdot 9-3 \cdot 4 \mathrm{mg} / \mathrm{g}$ dry matter (Table 4 ). However, by $18.00 \mathrm{~h}$ it had fallen to $0.9-2 \cdot 2 \mathrm{mg} / \mathrm{g}$ dry matter (Table 2) and the reticulo-rumen then contained $5 \cdot 9-13^{\cdot} \cdot 8 \mathrm{~g} \mathrm{Cr}_{2} \mathrm{O}_{3}$. In the morning, before feeding, the concentration of $\mathrm{Cr}_{2} \mathrm{O}_{3}$ had declined to ${ }_{\mathrm{I}} \cdot \mathrm{I}-\mathrm{I} \cdot 8 \mathrm{mg} / \mathrm{g}$ dry matter and the weight of $\mathrm{Cr}_{2} \mathrm{O}_{3}$ to $3 \cdot 9-6 \cdot 6 \mathrm{~g}$.

Comparison of the weight and concentration of $\mathrm{Cr}_{2} \mathrm{O}_{3}$ in the reticulo-rumen during parts $I$ and 2 of the experiment suggests that the excretion rate was more even during part I, when the marker was given before eating, than during part 2, when it was given at the end of eating. However, even in part $\mathrm{I}$ it was clear that a rapid passage of $\mathrm{Cr}_{2} \mathrm{O}_{3}$ from the reticulo-rumen took place during the course of the feed.

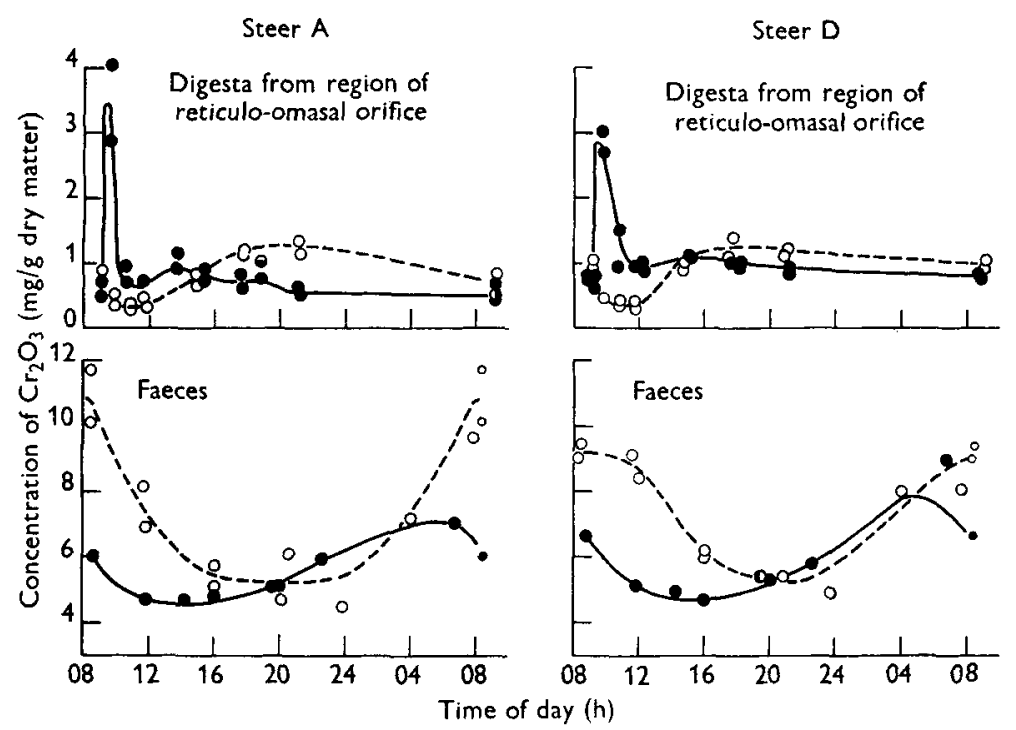

Fig. 3. Exp. 2. Concentration of $\mathrm{Cr}_{2} \mathrm{O}_{3}$ in digesta from the region of the reticulo-omasal orifice and in faeces of steers $\mathrm{A}$ and $\mathrm{D}$ given $20 \mathrm{~g} \mathrm{Cr}_{2} \mathrm{O}_{3}$ in capsules either before (09.10 h), - -0 , or after (about $12.30 \mathrm{~h}$ ), $\mathrm{O}--\mathrm{O}$, eating a single daily meal. Values for the faecal concentration in the period $08.00-10.00 \mathrm{~h}$ have been repeated on the right of the figure with small circles.

The concentrations of $\mathrm{Cr}_{2} \mathrm{O}_{3}$ in the samples of digesta from the region of the reticuloomasal orifice and in the faeces are shown in Fig. 3. The values confirm that the concentration of $\mathrm{Cr}_{2} \mathrm{O}_{3}$ in the digesta leaving the reticulo-rumen and in the faeces was even less variable in part $\mathrm{I}$ than in part 2. In part $\mathrm{I}$ the $\mathrm{Cr}_{2} \mathrm{O}_{3}$ content of these digesta was rather lower $(0.4-0.8 \mathrm{mg} / \mathrm{g}$ dry matter) than the mean value for the whole mixed contents at that time. Shortly after the introduction of the capsules there was the inevitable temporary increase in concentration, but within $2 \mathrm{~h}$, during which eating continued, the concentration had fallen to approximately the prefeeding level. It is interesting that here, as in Exp. I, there was a distinct increase in the concentration of $\mathrm{Cr}_{2} \mathrm{O}_{3}$ in the samples from the reticulo-omasal orifice, after the end of the feed. The concentration then fell gradually with gradients similar to those found in Exp. I until $2, \mathrm{I} .00 \mathrm{~h}$, and then more slowly until the next meal the following day. Apart from the 
samples taken immediately after feeding the variation in concentration was very small, in steer $\mathrm{A}$ the range being $0^{\circ} 4^{-\mathrm{I}} \cdot \mathrm{I}$ and in steer $\mathrm{D} 0.7^{-\mathrm{I}} \cdot 2 \mathrm{mg} / \mathrm{g}$ dry matter.

In part 2 the administration of $\mathrm{Cr}_{2} \mathrm{O}_{3}$ at the end of feeding gave rise to very much more variable concentrations in the digesta close to the orifice, as would be expected from the amounts found in the total contents. In both steers the concentration before feeding was $0 \cdot 6-1 \cdot 0 \mathrm{mg} / \mathrm{g}$ dry matter, but it then declined as the meal was being consumed, values as low as $0.3 \mathrm{mg}$ being recorded in both steers. It is probable that a temporary high value would have been recorded if the digesta had been sampled soon after the administration of $\mathrm{Cr}_{2} \mathrm{O}_{3}$. Such samples were not taken, but it was interesting to observe that the concentration of $\mathrm{Cr}_{2} \mathrm{O}_{3}$ rose until about $18.00 \mathrm{~h}$, was steady at about the same value at $2 \mathrm{r} .00 \mathrm{~h}$ and then presumably declined until the beginning of the next meal. The range of concentration was greater in this part of the experiment than in part $I$ and amounted to $0 \cdot 3^{-1} \cdot 3$ in steer A and $0 \cdot 3^{-1} \cdot 4 \mathrm{mg} / \mathrm{g}$ dry matter in steer D.

The concentration of $\mathrm{Cr}_{2} \mathrm{O}_{3}$ in the faeces (Fig. 3) was markedly influenced by the time of administration. In both parts of the experiment there was in every $24 \mathrm{~h}$ one period of high and another of low concentration. In part $\mathrm{I}$ the peak was apparently at about $06.00 \mathrm{~h}$, although there were insufficient samples to determine it accurately, and the low point was in the period $14.00-16.00 \mathrm{~h}$. In steer $A$ the overall range was $4.7^{-}$ $7.0 \mathrm{mg}$ and in steer D $4 \cdot 7-9.0 \mathrm{mg} / \mathrm{g}$ dry matter. In part 2 by contrast the peak came at about $08.00 \mathrm{~h}$ and the low point at about $20.00-22.00 \mathrm{~h}$, but the range was much wider, amounting in steer A to $4^{\cdot} \mathrm{I}-\mathrm{I} I \cdot 8$ and in steer D to $4^{\cdot} 9^{-}-9^{\circ} 4 \mathrm{mg} / \mathrm{g}$ dry matter.

Further calculations based on the results of Exps. 1 and 2

Further calculations have been made with the results of the two experiments to determine how the rate of passage of $\mathrm{Cr}_{2} \mathrm{O}_{3}$ from the reticulo-rumen compared with the rate of disappearance (by passage and by absorption) of dry matter. 'The values obtained are grouped in Tables 3 and 4 and are best considered under the following headings.

Rate of passage of $\mathrm{Cr}_{2} \mathrm{O}_{3}$ present in the reticulo-rumen before feeding. In part 2 of Exp. 2 no $\mathrm{Cr}_{2} \mathrm{O}_{3}$ was given during feeding and it may be presumed that the $\mathrm{Cr}_{2} \mathrm{O}_{3}$ present in the reticulo-rumen was well mixed with the digesta. Under these circumstances the weight of $\mathrm{Cr}_{2} \mathrm{O}_{3}$ declined at much the same rate as the weight of dry matter, and at the end of the feed there remained in the reticulo-rumen $72-9 \mathrm{I} \%$ (mean $80 \%$ ) of the $\mathrm{Cr}_{2} \mathrm{O}_{3}$ and $83-86 \%$ (mean $84 \%$ ) of the dry matter, present at the beginning and added during the feed.

Rate of passage of $\mathrm{Cr}_{2} \mathrm{O}_{3}$ added at the beginning of the feed. Under the conditions of Exp. I it was not known how rapidly $\mathrm{Cr}_{2} \mathrm{O}_{3}$ remaining from earlier administrations passed from the reticulo-rumen. The exact rate of loss of the $10 \mathrm{~g}$ given soon after the beginning of each feed could not, therefore, be determined. It is clear, however, (Table 3) that the loss was high, since although at the end of the meal there remained $77-94 \%$ (mean $87 \%$ ) of the dry matter there was only $43-48 \%$ (mean $45 \%$ ) of the $\mathrm{Cr}_{2} \mathrm{O}_{3}$ present at the beginning and added during the meal. Assuming that the $\mathrm{Cr}_{2} \mathrm{O}_{3}$ present initially declined at the same rate as the dry matter (value $f$ in Table 3 ), as was 


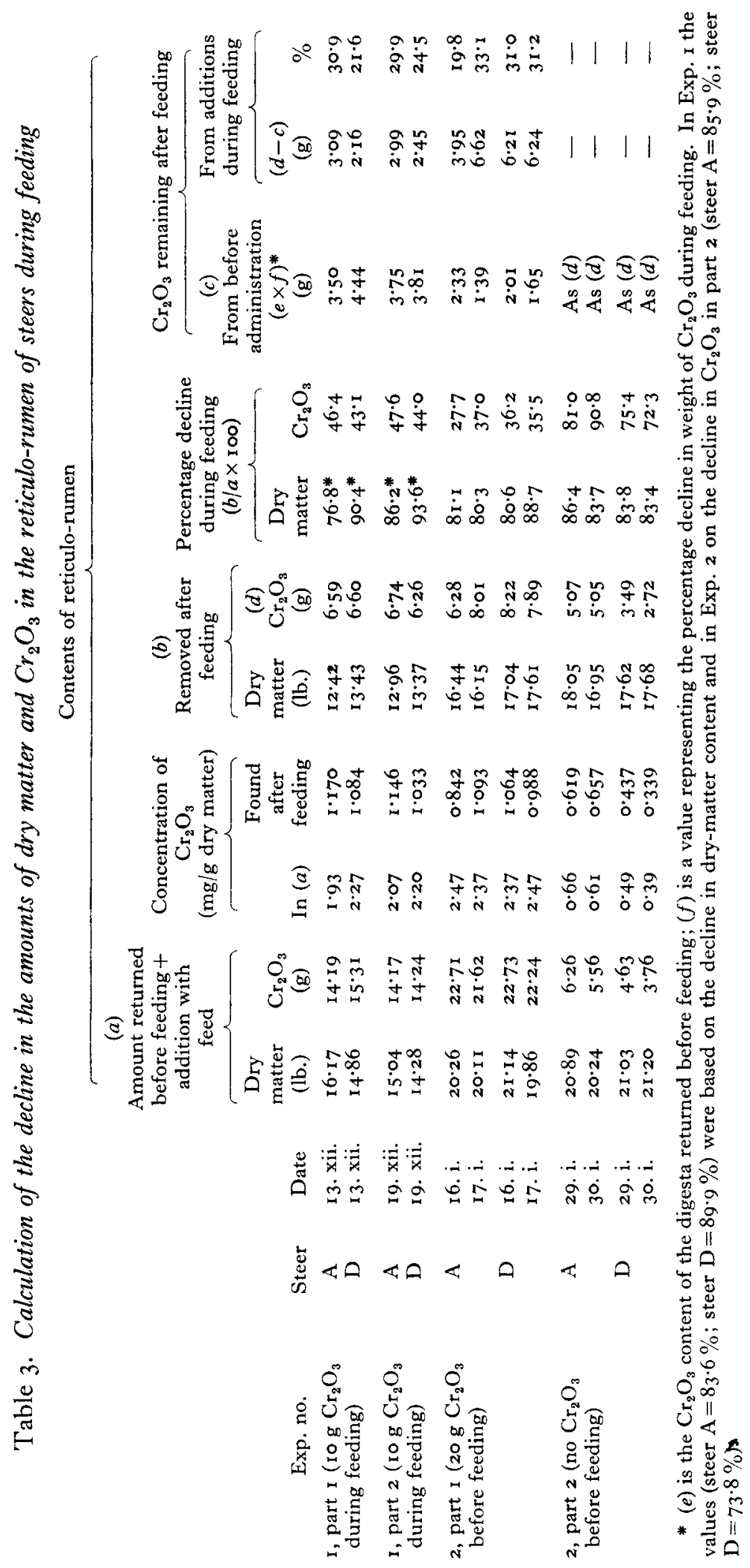


found in Exp. 2, part 2, it may be calculated that of the $\mathrm{Cr}_{2} \mathrm{O}_{3}$ given at the beginning of the feed only $22-3 \mathrm{I} \%$ (mean $27 \%$ ) remained in the reticulo-rumen at the end.

It was reasonable to assume that in Exp. 2, part $\mathrm{I}$, the $\mathrm{Cr}_{2} \mathrm{O}_{3}$ found before feeding declined at the rate actually observed for such residual $\mathrm{Cr}_{2} \mathrm{O}_{3}$ in part 2. On this basis it was calculated that of the $20 \mathrm{~g} \mathrm{Cr}_{2} \mathrm{O}_{3}$ given at the beginning of the feed only $20-33 \%$ (mean 29\%) remained in the reticulo-rumen at the end. The agreement with the less reliable value for Exp. I is good.

Rate of passage after feeding of $\mathrm{Cr}_{2} \mathrm{O}_{3}$ present before feeding. Further calculations, given in Table 4 , showed that in Exp. I the weight of $\mathrm{Cr}_{2} \mathrm{O}_{3}$ in the reticulo-rumen at the end of the feed declined to $65-78 \%$ (mean $69 \%$ ) in about $9.5 \mathrm{~h}$ after the feed, whereas in the same period the dry-matter content declined to $63-86 \%$ (mean $71 \%$ ). In Exp. 2, part $\mathrm{I}$, the $\mathrm{Cr}_{2} \mathrm{O}_{3}$ present $6 \mathrm{~h}$ after the end of feeding was $59-82 \%$ (mean $74 \%$ ) of the amount present when the feed ended and the corresponding values for dry matter were $74-83 \%$ (mean $80 \%$ ).

These values, obtained in both experiments, suggest that once $\mathrm{Cr}_{2} \mathrm{O}_{3}$ has become well mixed with the digesta its rate of passage from the reticulo-rumen is probably not markedly different from that of dry matter.

Rate of passage of $\mathrm{Cr}_{2} \mathrm{O}_{3}$ given after feeding. Assuming that in part 2 of Exp. 2 the residual $\mathrm{Cr}_{2} \mathrm{O}_{3}$ present at the end of feeding declined at the same rate as in part $\mathbf{I}$ (value $f$ in Table 4 ), it was calculated that of the $20 \mathrm{~g} \mathrm{Cr}_{2} \mathrm{O}_{3}$ given at the end of the feed I0-49\% (mean $30 \%$ ) remained $6 \mathrm{~h}$ later. The value for steer A on 30 January was so discordant that a manipulative error is suspected; without this value the range was $26-49 \%$ and the mean $36.9 \%$. In spite of their variation these values show that even when $\mathrm{Cr}_{2} \mathrm{O}_{3}$ is given after feeding there is a period, presumably initially, when its rate of passage from the reticulo-rumen is considerably more rapid than that of dry matter.

\section{DISCUSSION}

These experiments showed that in the first $30-60$ min after $\mathrm{Cr}_{2} \mathrm{O}_{3}$ in capsules was administered to steers, a large proportion passed from the reticulo-rumen to the omasum without becoming evenly mixed with digesta. Inevitably this resulted in uneven excretion in the faeces. It seems unlikely that the uneven excretion can be avoided when $\mathrm{Cr}_{2} \mathrm{O}_{3}$ or any other marker is given in concentrated form such as capsules. The results of Kane et al. (1952) suggest that the range of $\mathrm{Cr}_{2} \mathrm{O}_{3}$ concentration in the faeces would be reduced if the $\mathrm{Cr}_{2} \mathrm{O}_{3}$ were given in a form in which it would be carried into the rumen. In many grazing experiments the 'macaroni' used in Scandinavia (Edin et al. 1944-5) might be suitable for this purpose. Irrespective of the method of administration it would seem desirable to give the $\mathrm{Cr}_{2} \mathrm{O}_{3}$ twice daily before the main periods of grazing, for example during the times that cows are in the shed for milking. This precaution will ensure that the maximum passage of $\mathrm{Cr}_{2} \mathrm{O}_{3}$ from the reticulo-rumen coincides with the maximum passage of dry matter (Balch, unpublished).

In grazing experiments the choice of two satisfactory times of day at which to take faeces samples must clearly be made with great care. The samples must be taken at 


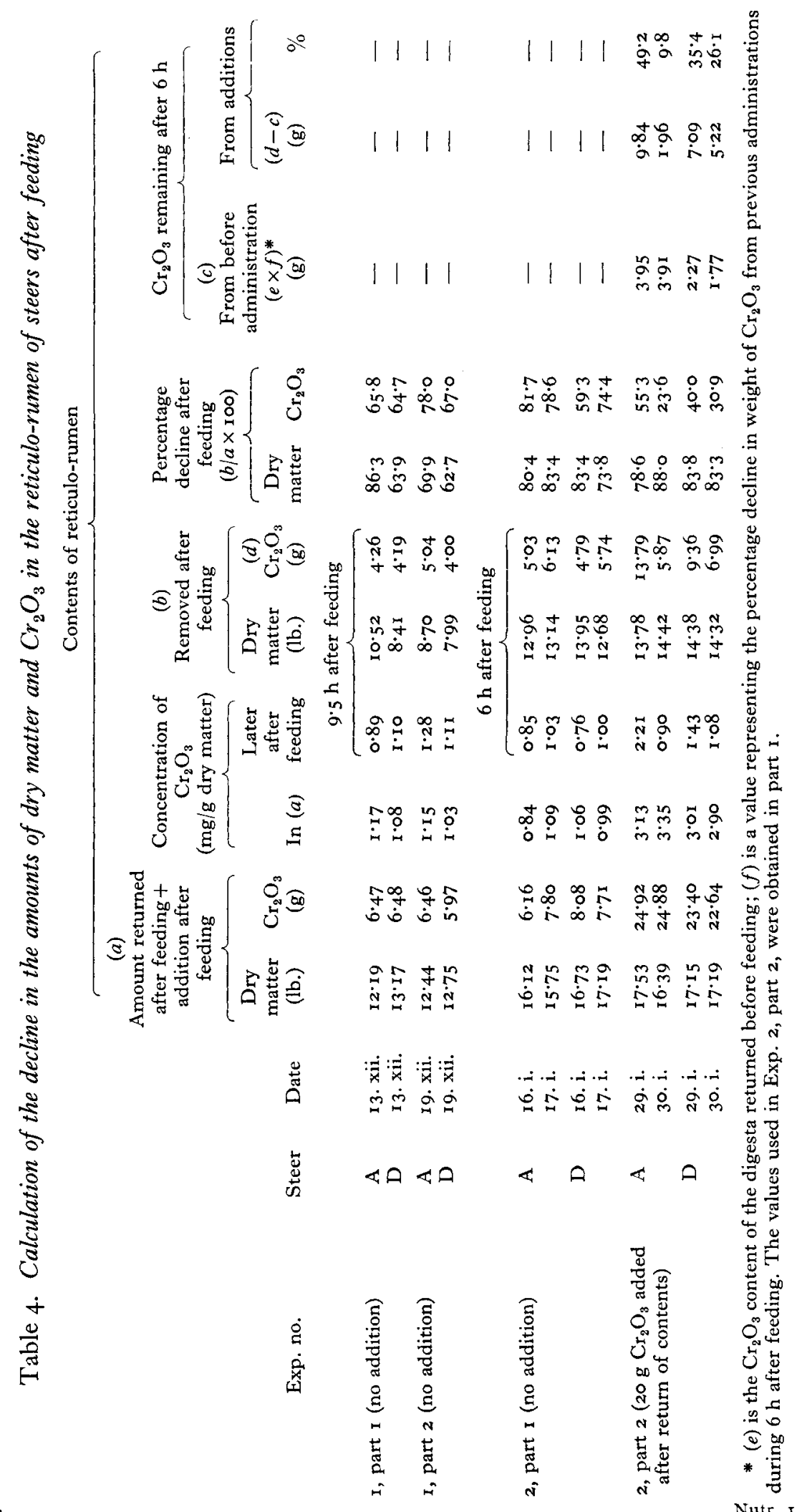


times when the concentration of $\mathrm{Cr}_{2} \mathrm{O}_{3}$ is such that values for composite samples made up of equal weights of faeces from each sampling on several days will have the same composition as well-mixed samples from all the faeces produced in the same period. The amplitude and time of peaks and low points on the excretion curve for $\mathrm{Cr}_{2} \mathrm{O}_{3}$ will vary under different conditions of feeding and management. Differences between indoor and grazing conditions have already been demonstrated (Hardison \& Reid, I953; Kane et al. 1952). With twice daily administration of $\mathrm{Cr}_{2} \mathrm{O}_{3}$ at intervals of 8 and $16 \mathrm{~h}$ Kane $e t$ al. observed only one peak in $24 \mathrm{~h}$ and one low point. The way in which the $\mathrm{Cr}_{2} \mathrm{O}_{3}$ from two administrations, separated by a $9 \mathrm{~h}$ interval, was combined to form a single peak was well demonstrated in sheep by Lambourne (r955). This worker also found that the rate of excretion of a single dose of $\mathrm{Cr}_{2} \mathrm{O}_{3}$ was slower on hay diets than with young grass; with hay the first appearance and peak of excretion were later by I 2-1 $8 \mathrm{~h}$, an approximate doubling of the time required for passage through the digestive tract. This observation offers an explanation for the different times of the peak and low point of excretion found by American workers (p. I84). The results of the present experiments suggest that the time of feeding and the time of administration of the $\mathrm{Cr}_{2} \mathrm{O}_{3}$ may all influence the time of peak and low concentration of $\mathrm{Cr}_{2} \mathrm{O}_{3}$ in the faeces. It is also likely that the concentration will be influenced by the activity of the animals and the amount and type of grazing.

It appears unlikely that a method of giving $\mathrm{Cr}_{2} \mathrm{O}_{3}$ to grazing animals will be found that ensures an even excretion in the faeces and, although under conditions studied previously, sampling at $05.00-06.00 \mathrm{~h}$ and $\mathrm{I} 3.00-16.00 \mathrm{~h}$ gave satisfactory results it would be unwise to assume that it will necessarily be so in all experiments. It is therefore recommended that the suitability of the sampling times should be checked against complete collection of faeces under the conditions of each experiment. This would seem to be especially necessary where unusual crops or unusual grazing management are being used.

The concentration of $\mathrm{Cr}_{2} \mathrm{O}_{3}$ in the digesta found close to the reticulo-omasal orifice suggests that immediately after the administration of the capsule of $\mathrm{Cr}_{2} \mathrm{O}_{3}$ there was a short period of time in which the digesta passing to the omasum contained $\mathrm{Cr}_{2} \mathrm{O}_{3}$ in very high concentration. No faeces samples of correspondingly high $\mathrm{Cr}_{2} \mathrm{O}_{3}$ content were found, but instead a gradual rise and fall in concentration were observed. This suggests that the digesta undergo a certain degree of mixing after they have left the reticulorumen.

Since the digesta lying close to the reticulo-omasal orifice must be similar in composition to those passing through the orifice, it was suggested earlier (Balch, 1949) that representative samples might be employed in conjunction with the $\mathrm{Cr}_{2} \mathrm{O}_{3}$ ratio technique for the determination of the extent of digestion in the reticulo-rumen. The attempt failed, as any similar attempt in the present experiments would have failed, because the ratio of $\mathrm{Cr}_{2} \mathrm{O}_{3}$ to dry matter in the digesta close to the orifice was lower than that in either the food or the faeces. The cause of this obvious breakdown of the method was clearly the rapid initial excretion of the $\mathrm{Cr}_{2} \mathrm{O}_{3}$. 
SUMMARY

1. The effects of lying and standing and of the time of administration of capsules of $\mathrm{Cr}_{2} \mathrm{O}_{3}$ on the concentration of $\mathrm{Cr}_{2} \mathrm{O}_{3}$ in the faeces were determined in two steers with rumen fistulas. The steers were given a diet of hay and concentrates in either one or two feeds daily.

2. Capsules of $\mathrm{Cr}_{2} \mathrm{O}_{3}$ entered the anterior rumen or the reticulum and dissolved in about 5 min, releasing the $\mathrm{Cr}_{2} \mathrm{O}_{3}$ and allowing its admixture with the contents of those regions. During the first $30-60 \mathrm{~min}$ after administration there was a rapid transfer of $\mathrm{Cr}_{2} \mathrm{O}_{3}$ to the omasum. Of the $\mathrm{Cr}_{2} \mathrm{O}_{3}$ given at the beginning of feeding less than $33 \%$ remained when the meal had been completed. Once the $\mathrm{Cr}_{2} \mathrm{O}_{3}$ had become mixed with the contents of the reticulo-rumen the amount present declined at much the same rate as the dry matter of the contents.

3. The rate of passage of $\mathrm{Cr}_{2} \mathrm{O}_{3}$ and the disappearance of dry matter and of water from the reticulo-rumen were the same when the animal was standing as when it was lying. Posture therefore exerted no marked effect on the concentration of $\mathrm{Cr}_{2} \mathrm{O}_{3}$ in the faeces.

4. Administration of $\mathrm{Cr}_{2} \mathrm{O}_{3}$ immediately before a single daily feed caused a more even excretion of $\mathrm{Cr}_{2} \mathrm{O}_{3}$ in the faeces than administration immediately after the feed.

5. It is recommended that in grazing experiments employing $\mathrm{Cr}_{2} \mathrm{O}_{3}$ it should be given at the beginning of the main daily periods of grazing. It is also suggested that the suitability of any given scheme of $\mathrm{Cr}_{2} \mathrm{O}_{3}$ administration and of faeces sampling should be checked against a complete collection of faeces under the conditions of each experiment.

\section{REFERENCES}

Balch, C. C. (1949). Some factors influencing the intake and digestion of foods by dairy cows. Ph.D. Thesis, University of Reading.

Balch, C. C. \& Johnson, V. W. (1948). Vet. Rec. 6o, 446.

Bolin, D. W., King, R. P. \& Klosterman, E. W. (1952). Science, Ir 6, 634.

Edin, H., Kihlén, G. \& Nordfeldt, S. (1944-5). LantbrHögsk. Ann. 12, 166.

Hardison, W. A. \& Reid, J. T. (1953). F. Nutr. 51, 35.

Kane, E. A., Jacobson, W. C. \& Moore, L. A. (1952). F. Nutr. 47, 263.

Lambourne, L. J. (1955). Proc. N.Z. Soc. Anim. Prod. 15, 36. 